\title{
Temporal gradient of recovery of a conditioned emotional response following a single electroconvulsive shock
}

\author{
MARVIN NACHMAN, RICHARD O. \\ $M E I N E C K E$, and H. DALE BAUMBACH, \\ University of California, Riverside, Calif. \\ 92502
}

Rats which had been previously trained to drink in a test cage were given a footshock on 2 successive days in that cage to establish a CER. On the 3rd day, an ECS was given, and the amount drunk in the test cage was used as a measure of suppression of the CER. In tests administered $20 \mathrm{~min}, 45 \mathrm{~min}$, $90 \mathrm{~min}, 4 \mathrm{~h}$, and $24 \mathrm{~h}$ after the ECS, the amount drunk was found to be a decreasing function of the ECS/test-time interval. $A$ final retest $24 \mathrm{~h}$ after the ECS indicated that all $S$ s had recovered the CER. The implications of these results are discussed for studies involving ECS-produced retrograde amnesia.

In a series of experiments, Hunt and his colleagues (reviewed in Hunt, 1965) tested the effects of multiple electroconvulsiveshock (ECS) treatments given several days after the establishment of a well learned conditioned emotional response (CER) in rats. They found that a series of from 7 to 21 ECS treatments resulted in a temporary suppression of the CER. The Ss showed recovery of the CER sometime between 4 and 30 days after the last ECS, with the course of recovery depending in part on the number and spacing of the ECS treatments. Spevack \& Suboski (1967) similarly found that a series of 7 ECS treatments produced a suppression of an avoidance response in rats when the animals were tested $48 \mathrm{~h}$ later.
In recent years, most of the experimental work on the effects of ECS on retrograde amnesia or on a CER has utilized only a single ECS treatment in order to avoid the possible punishing or debilitating effects of multiple treatments. Since a series of ECS treatments results in a temporal gradient of suppression of a CER lasting over days or weeks, it seemed likely that a single ECS might also show a similar gradient of suppression of a CER, but telescoped into a much smaller time period. This idea is supported by a recent study of Kopp, Bohdanecky, \& Jarvik (1967) in which they found that a single ECS given to mice $1.8 \mathrm{~h}$ before a step-through test could result in a disruptive effect on an avoidance response.

The present study was designed to establish a CER in rats and then to measure the effects of a single ECS on the temporal gradient of suppression of that CER.

$$
\text { METHOD }
$$

Fifty-eight 90-day-old male Sprague-Dawley rats from the Holtzman Company were given water for $1 \mathrm{~h}$ a day in their home cages throughout the experiment. After 2 days on this schedule, Ss were given two training sessions a day for 3 days in a wooden box, $30 \times 17 \times 17 \mathrm{~cm}$, which had an electrifiable grid floor. Training sessions were about $5 \mathrm{~min}$ each, during which time a guillotine door was raised and lowered several times, until Ss would start drinking as soon as the door exposed a drinking spout.

After drinking training, Ss were divided randomly into seven groups, and were given a 3-min drinking test on Days 47 when $22 \mathrm{~h}$ water deprived. The drinking tests began by raising the guillotine door, $30 \mathrm{sec}$ after $\mathrm{S}$ was placed into the box. Latency to drink for 10 . consecutive seconds and amount drunk were measured in the 3-min test.

On Days 4 and 5, Groups 1-6 received CER training by the administration of a 1.7-mA footshock (FS) for $2 \mathrm{sec}$, delivered through the grid floor at the end of the 3-min drinking test. Although a single FS is usually sufficient to produce inhibition of drinking in most Ss in this test, FS was given on both Days 4 and 5 to ensure that the CER was firmly established in all Ss. Group 7, a no-FS control, was merely removed to the home cage following the drinking test on Days 4 and 5.

On Day 6, Groups $1-5$ and Group 7 were given an ECS and then, at various time intervals, were placed in to the drinking box and tested as follows: Group $1(\mathrm{~N}=9)$ was tested for drinking $20 \mathrm{~min}$ after the ECS; Group $2(\mathrm{~N}=8)$ was tested 45 min later; Group $3(\mathrm{~N}=8)$ was tested $90 \mathrm{~min}$ later; Group $4(N=8)$ was tested $4 \mathrm{~h}$ later; Group $5(\mathrm{~N}=8)$ was tested $24 \mathrm{~h}$ later. Group $7(N=9)$, the no-FS control, was also tested $20 \mathrm{~min}$ after the ECS. Group 6 $(\mathrm{N}=8)$, the no-ECS control, was merely given the 3-min test. For the ECS treatment, Ss were removed from the home cage, given the ECS while held in E's hand, and then returned to their respective home cages for recovery during the ECS-test interval. The ECS $(55-60 \mathrm{~mA}$ for $.20 \mathrm{sec}$ ) was delivered via modified alligator clips attached to the pinnae.

On Day 7, all groups were given a final 3-min drinking test. (For Group 5, this final test occurred a day later because Group 5 was the 24-h ECS-test interval group.)

$$
\text { RESULTS }
$$

Table 1 contains medians and interquartile ranges for amounts drunk and latencies to drink on each day. All statistical tests are reported for amounts drunk, since

Table 1

\begin{tabular}{|c|c|c|c|c|c|c|c|c|c|c|c|}
\hline \multirow[b]{2}{*}{ Group } & \multirow[b]{2}{*}{$\mathbf{N}$} & \multirow[b]{2}{*}{$\begin{array}{l}\text { ECS-Test } \\
\text { Interval } \\
\end{array}$} & & \multicolumn{4}{|c|}{ Amount (in $\mathrm{ml}$ ) } & \multicolumn{4}{|c|}{ Latency (in sec) } \\
\hline & & & & $\begin{array}{c}\text { Day } 4 \\
\text { Test-FS }\end{array}$ & $\begin{array}{c}\text { Day } 5 \\
\text { Test-FS }\end{array}$ & $\begin{array}{c}\text { Day } 6 \\
\text { ECS-Test }\end{array}$ & $\begin{array}{l}\text { Day } 7 \\
\text { Test }\end{array}$ & $\begin{array}{c}\text { Day } 4 \\
\text { Test-FS }\end{array}$ & $\begin{array}{c}\text { Day } 5 \\
\text { Test-FS } \\
\end{array}$ & $\begin{array}{c}\text { Day } 6 \\
\text { ECS-Test }\end{array}$ & $\begin{array}{r}\text { Day } 7 \\
\text { Test }\end{array}$ \\
\hline 1 & 9 & $20 \mathrm{~min}$ & $\begin{array}{l}\text { Median } \\
\text { IQ Range }\end{array}$ & $\begin{array}{c}7.4 \\
6.4-7.9\end{array}$ & $\begin{array}{l}1.0 \\
0-2.2\end{array}$ & $\begin{array}{c}5.9 \\
2.8-6.2\end{array}$ & $\stackrel{0}{0-0}$ & $\begin{array}{c}2 \\
1-5\end{array}$ & $\begin{array}{c}180 \\
87-180\end{array}$ & $\begin{array}{c}7 \\
3-167\end{array}$ & $\begin{array}{c}180 \\
180-180\end{array}$ \\
\hline 2 & 8 & $45 \mathrm{~min}$ & $\begin{array}{l}\text { Median } \\
\text { I-Q Range }\end{array}$ & $\begin{array}{c}8.0 \\
6.8-8.6\end{array}$ & $\begin{array}{l}0.6 \\
0-2.8\end{array}$ & $\begin{array}{l}3.3 \\
0-6.5\end{array}$ & $\begin{array}{c}0 \\
0-0\end{array}$ & $\begin{array}{c}1 \\
1-2\end{array}$ & $\begin{array}{c}180 \\
56-180\end{array}$ & $\begin{array}{c}82 \\
6-180\end{array}$ & $\begin{array}{c}180 \\
180-180\end{array}$ \\
\hline 3 & 8 & $90 \mathrm{~min}$ & $\begin{array}{l}\text { Median } \\
\text { I-Q Range }\end{array}$ & $\begin{array}{c}7.8 \\
6.4-8.5\end{array}$ & $\begin{array}{c}0.6 \\
0-2.4\end{array}$ & $\begin{array}{l}0 \\
0-2.3\end{array}$ & $\stackrel{0}{0-0}$ & $1-4$ & $\begin{array}{c}180 \\
137-180\end{array}$ & $\begin{array}{c}180 \\
109-180\end{array}$ & $\begin{array}{c}180 \\
180-180\end{array}$ \\
\hline 4 & 8 & $4 h$ & $\begin{array}{l}\text { Median } \\
\text { I-Q Range }\end{array}$ & $\begin{array}{c}7.8 \\
7.0-8.8\end{array}$ & $\begin{array}{c}1.0 \\
0.1-1.4\end{array}$ & $\begin{array}{l}0 \\
0-0\end{array}$ & $\stackrel{0}{0-0}$ & 1 & $\begin{array}{c}180 \\
162-180\end{array}$ & $\begin{array}{c}180 \\
180-180\end{array}$ & $\begin{array}{c}180 \\
180-180\end{array}$ \\
\hline 5 & 8 & $24 \mathrm{~h}$ & $\begin{array}{l}\text { Median } \\
\text { I-Q Range }\end{array}$ & $\begin{array}{c}7.5 \\
7.2-7.8\end{array}$ & $\begin{array}{l}0 \\
0-2.7\end{array}$ & $\begin{array}{l}0 \\
0-0\end{array}$ & $\begin{array}{c}0 \\
0-0\end{array}$ & $\begin{array}{c}1 \\
1-2\end{array}$ & $\begin{array}{c}180 \\
94-180\end{array}$ & $\begin{array}{c}180 \\
180-180\end{array}$ & $\begin{array}{c}180 \\
180-180\end{array}$ \\
\hline 6 & 8 & No ECS & $\begin{array}{l}\text { Median } \\
\text { I-Q Range }\end{array}$ & $\begin{array}{c}7.2 \\
7.0-8.0\end{array}$ & $\begin{array}{c}1.4 \\
0-2.6\end{array}$ & $\begin{array}{l}0 \\
0-0\end{array}$ & $\begin{array}{c}0 \\
0-0\end{array}$ & $\stackrel{2}{1-8}$ & $\begin{array}{c}138 \\
112-180\end{array}$ & $\begin{array}{c}180 \\
180-180\end{array}$ & $\begin{array}{c}180 \\
180-180\end{array}$ \\
\hline 7 & 9 & $\begin{array}{l}20 \mathrm{~min} \\
\text { (No FS) }\end{array}$ & $\begin{array}{l}\text { Median } \\
\text { I-Q Range }\end{array}$ & $\begin{array}{c}7.9 \\
6.0-8.2 \\
\end{array}$ & $\begin{array}{c}7.2 \\
5.9-7.7 \\
\end{array}$ & $\begin{array}{c}6.3 \\
5.2-7.3 \\
\end{array}$ & $\begin{array}{c}7.1 \\
6.4-8.2 \\
\end{array}$ & $\begin{array}{c}2 \\
1-3\end{array}$ & $\begin{array}{r}1 \\
1-2 \\
\end{array}$ & $\begin{array}{c}2 \\
1-15\end{array}$ & $\begin{array}{r}1 \\
1-1\end{array}$ \\
\hline
\end{tabular}

Medians and Interquartile (I-Q) Ranges for Amounts Drunk and Latencies to Drink for Ten Consecutive Seconds 


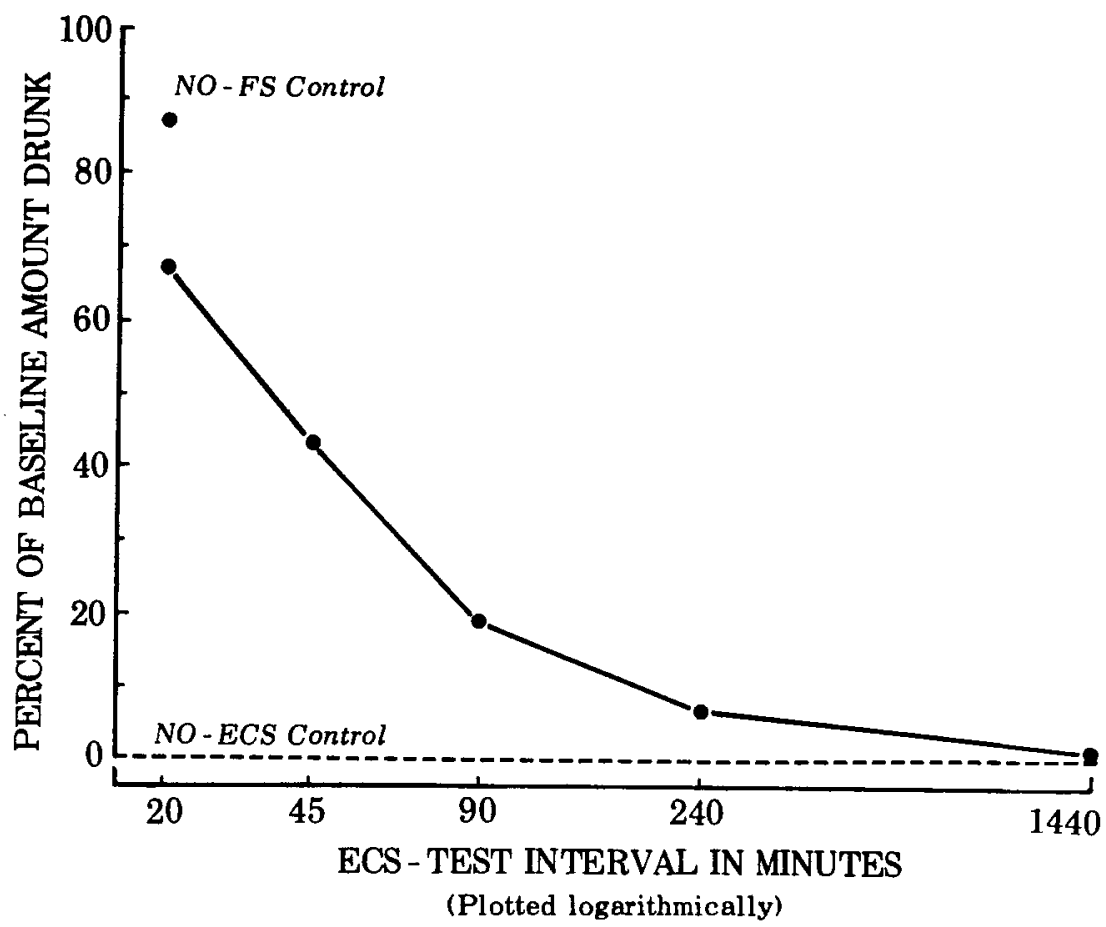

in all cases but one (clarified below) significance decisions based on either measure are the same. There were no significant differences among all groups on Day 4, prior to the first FS ( $>>1$, Kruskal-Wallis test). Further, the Day 4 CER training was learned equally well by all punished groups, i.e., there were no significant differences among Groups 1.6 on Day $5(\mathrm{p}>.1$, Kruskal-Wallis test).

On Day 6, the amount that each group drank was found to be a function of the time interval between the ECS and the test. Figure 1 contains, for each time interval, the mean amount drunk by each group on Day 6, expressed as a percentage of its mean amount drunk on Day 4. The gradient reflected at the various post-ECS intervals shows that the suppression of the CER produced by ECS had almost completely disappeared within $4 \mathrm{~h}$. Mann-Whitney $\mathrm{U}$ tests indicated that whereas Groups 1 and 2 drank significantly more than Group 6(FS only) ( $\mathrm{p}<.01$ and $\mathrm{p}<.025$, respectively), Groups 3,4 , and 5 were not significantly different from Group 6 (ps $>.1$ ).

The amount drunk by Group 7 on Day 6 was only slightly depressed and was not significantly different from its Day 4 baseline $(\mathrm{p}>.1$, sign test), indicating that the ECS given to them $20 \mathrm{~min}$ before the drinking test did not greatly alter their drinking performance. Group 1 was not significantly different from Group 7 on Day 6 ( $p>.1$, Mann-Whitney U test), although when compared with its own Day 4 performance, a significant difference was found between the Group 1 amounts
Fig. 1. Day 6 mean amounts drunk by each group as a function of the time after ECS that the group was tested. Mean amount drunk on Day 6 by each group is expressed as the per cent of its own mean baseline (Day 4) amount drunk.

implications for those studies which use a one-trial FS-ECS paradigm such as step-down or step-through procedures. In these procedures, an animal that remains on the platform the day following the FS treatment is often assumed to have learned a passive-avoidance response, whereas the animal that leaves the platform the day following a FS-ECS treatment is assumed to have not learned-or to be amnesic for-the passive-avoidance response. Alternatively, as several authors have pointed out (Chorover \& Schiller, 1966; Pinel, 1968), an animal that remains on the platform may simply be emitting a freezing reaction, or CER. Since a single ECS treatment can suppress the CER, the fact that a rat steps down more rapidly may represent temporary loss of the freezing response rather than amnesia and may thus confound the amnesia interpretation. It is possible that the "recovery from amnesia" which has been reported in some studies (e.g., Zinkin \& Miller, 1967; Riddell, 1969) is related to the recovery from temporary suppression of a CER.

\section{REFERENCES}

CHOROVER, S. L., \& SCHILLER, P. H. Reexamination of prolonged retrograde amnesia in one-trial learning. Journal of Comparative \& Physiological Psychology, 1966, 61, 34-41.

The results of this experiment demonstrate that one ECS can disrupt strong CER training given to rats $24 \mathrm{~h}$ and $48 \mathrm{~h}$ earlier. This disruptive effect was temporary, since the CER regained strength with time and reached recovery within $4 \mathrm{~h}$. All animals invariably showed complete CER recovery $24 \mathrm{~h}$ after the ECS.

The results of this experiment are highly similar to those first reported by Hunt \& Brady (1951), in which they used multiple ECS treatments and longer time spans. As was the case in their studies, however, there is little understanding of the way in which ECS produces a temporary disruption of the CER. It is possible that the CER was suppressed shortly after the ECS in our study because of a general disorientation or debilitation. However, it is clear that the drinking response per se was only slightly affected by the ECS, and, in other work in our laboratory, it has been found that rats trained to press in a Skinner box performed at near normal rates $20 \mathrm{~min}$ after an ECS. Thus, the temporary suppression produced by ECS appears to be selective to the CER.

Although the present experiment was not directly concerned with studying the retrograde amnesic effects of ECS, it has
HUNT, H. F. Electro-convulsive shock and learning. Transactions of the New York Academy of Sciences, 1965, 27, 923-945.

HUNT, H. F., \& BRADY, J. F. Some effects of electro-convulsive shock on a conditioned emotional response ("anxiety"). Joumal of Comparative \& Physiological Psychology, 1951, 44, 88-98.

KOPP, R., BOHDANECKY, Z., \& JARVIK, M.E Proactive effect of a single ECS on step-through Journal of Comparative \& Physiological Psychology, 1967, 64, 22-25.

PINEL, J. P. J. Evaluation of the one-trial passive avoidance task as a tool for studying ECS-produced amnesia. Psychonomic Science, 1968, 13, 131-132.

RIDDELL, W. I. Effect of electroconvulsive amnesia. Journal of Comparative \& Physiological Psychology, 1969, 67, 140-143.

SPEVACK, A. A., \& SUBOSKI, M. D. A confounding of conditioned suppression in passive avoidance: ECS effects. Psychonomic Science, 1967, 9, 23-24.

ZINKIN, S., \& MILLR, A. J. Recovery of memory after amnesia induced by electroconvulsive shock. Science, 1967, 155, 102-104.

\section{NOTE}

1. National Science Foundation undergraduate summer research fellow. performance of naive and punished mice. shock: Permanent or temporary retrograde 